\title{
Upaya Meningkatkan Hasil Belajar Agama Islam Melalui Model Pembelajaran Kooperatif Tipe Talking Stick Pada Siswa SMA Negeri 1 Wonosari
}

\author{
Lestari Mustapa \\ Guru SMA Negeri 1 Wonosari \\ lestari@gmail.com
}

Received: 04 March 2021; Revised: 26 April 2021; Accepted: 28 July 2021

DOI: http://dx.doi.org/10.37905/aksara.7.3.1149-1154.2021

\begin{abstract}
ABSTRAK:
Tujuan dari penelitian adalah untuk meningkatkan hasil belajar peserta didik kelas XI SMA Negeri 1 Wonosari pada mata pelajaran Pendidikan Agama Islam. Penelitian yang dilakukan menggunakan penelitian tindakan kelas dengan sujek penelitian siswa kelas XI SMA Negeri 1 Wonosari.

Hasil dari penelitian ini penggunaan model pembelajaran kooperatif tipe talking stick dapat meningkatkan kualitas pembelajaran, baik menyangkut kegiatan guru, aktivitas peserta didik dalam pembelajaran, serta berdampak pada peningkatan hasil belajar peserta didik kelas XI SMA Negeri 1 Wonosari. Hal ini dapat dilihat pada hasil yang dicapai berikut ini : a) Aktivitas guru mengalami peningkatan, dari siklus I sebesar $76.92 \%$ yang terlaksana meningkat pada siklus II sebesar $100 \%$ yang terlaksana. b) Aktivitas peserta didik mengalami peningkatan, dari siklus I sebesar 54,54\% yang tuntas meningkat pada siklus II sebesar 100\% yang tuntas. c) Hasil belajar peserta didik mengalami peningkatan, dari siklus I sebesar $71,75 \%$ yang tuntas meningkat pada siklus II sebesar $100 \%$ yang tuntas.
\end{abstract}

Kata Kunci : kooperatif talking stick, hasil belajar siswa, PAI

\section{PENDAHULUAN}

Keberhasilan sebuah proses belajar mengajar sangat ditentukan oleh hasil belajar yang dicapai oleh peserta didik. Ketuntasan hasil belajar ini menjadi cermin dari keberhasilan guru dalam menerapkan metode pembelajaran, dan hasil belajar yang dicapai peserta didik sangat dipengaruhi oleh cara belajar peserta didik itu sendiri.

Pembelajaran Sains di Sekolah Menengah Pertama hendaknya membuka kesempatan untuk memupuk rasa ingin tahu peserta didik secara alamiah. Hal ini akan membantu peserta didik mengembangkan kemampuan bertanya dan mencari jawaban atas fenomena alam berdasarkan bukti serta mengembangkan cara berfikir ilmiah.

Fokus program pengajaran Sains hendaknya ditujukan untuk memupuk minat dan pengembangan peserta didik terhadap dunia mereka di lingkungan mereka hidup. Melalui pembelajaran Sains, peserta didik diajak untuk mengamati alam dan mencari tahu serta mengenal lingkungan sekitar. 
Namun kenyataan di lapangan tidak seperti itu. Pembelajaran yang dilakukan guru, selama ini masih menggunakan metode ceramah, sehingga pembelajaran hanya berfokus pada guru. Metode ini menyebabkan peserta didik tidak aktif selama proses pembelajaran, sehingga peserta didik tidak dapat mengembangkan materi yang seharusnya bisa dikembangkan melalui diskusi-diskusi dalam kelompok.

Permasalahan yang dihadapi di Kelas XI SMA Negeri 1 Wonosari, khususnya pembelajaran Pendidikan Agama Islam adalah kurangnya partisPendidikan Agama Islamsi dan respon peserta didik pada proses pembelajaran. Hal ini nampak pada kurangnya perhatian peserta didik pada saat guru menjelaskan, kurangnya kemampuan peserta didik dalam memecahkan soal-soal latihan, rendahnya hasil yang dicapai peserta didik pada evaluasi, serta kurangnya kemauan peserta didik untuk mengajukan pertanyaan maupun menjawab pertanyaan yang diajukan guru. Keadaan tersebut berpengaruh pada hasil ulangan harian yang diperoleh peserta didik, yang berimbas pada ketuntasan hasil belajar yang tidak sesuai dengan kriteria ketuntasan yang telah ditetapkan, yakni 75.

Secara umum rata-rata nilai Pendidikan Agama Islam Kelas XI SMA Negeri 1 Wonosari untuk tiga tahun terakhir cenderung mengalami peningkatan, namun belum mencapai standar ketuntasan yang dipersyaratkan pada mata pelajaran Pendidikan Agama Islam yakni rata-rata nilai minimal 75 . Hal ini disebabkan oleh kurangnya motivasi dan keaktifan peserta didik dalam belajar. Proses pembelajaran menggunakan metode ceramah menyebabkan peserta didik menjadi bosan dalam menerima pelajaran, sehingga berdampak pada hasil belajar yang dicapai oleh peserta didik.

Upaya yang dapat dilakukan untuk mengatasi hal tersebut adalah mengembangkan kurikulum, mengembangkan kualitas pembelajaran, peningkatan mutu tenaga pengajar, serta lingkungan belajar yang kondusif dan memadai (Prabowo, 2001: 75). Metode talking stick adalah salah satu metode pembelajaran yang dapat diterapkan, yaitu suatu metode pembelajaran dengan menggunakan tongkat sebagai alat bantu. Metode ini melatih peserta didik untuk berfikir cepat dalam pembelajaran sekaligus mengasah kemampuan peserta didik melalui pertanyaan-pertanyaan yang diberikan guru. Pada metode talking stick, peserta didik yang memegang tongkat wajib menjawab pertanyaan dari guru setelah peserta didik mempelajari materi pokok. Dengan memilih metode talking stick, diharapkan peserta didik selalu siap setiap pembelajaran, sehingga berdampak pada meningkatnya hasil belajar yang dicapai peserta didik.

\section{METODE PENELITIAN}

Penelitian Tindakan Kelas ini dilaksanakan di SMA Negeri 1 Wonosari. Peserta didik yang dikenai tindakan adalah peserta didik kelas $\mathrm{X}$, dengan jumlah peserta didik sebanyak 20 orang, terdiri dari 7 peserta didik laki-laki dan 9 peserta didik perempuan. Penelitian ini adalah penelitian bersiklus. Jika pada siklus 1 hasilnya tidak sesuai dengan standar ketuntasan, maka akan dilanjutkan pada siklus selanjutnya. Pertemuan siklus I dilaksanakan sebanyak 2 kali pertemuan. Penelitian akan dilaksanakan pada bulan Oktober 2018.

Pada tahap persiapan, peneliti menyiapkan segala sesuatu yang diperlukan sehubungan dengan pelaksanaan tindakan. Berbagai tindakan yang direncanakan dalam pembelajaran Pendidikan Agama Islam dilakukan dengan menggunakan model kooperatif tipe talking stick. Pelaksanaan tindakan yang dilakukan peneliti berdasarkan 
rancangan yang telah ditetapkan dan disusun sebelumnya, sebagaimana dalam Skenario Pembelajaran. Pada saat pelaksanaan tindakan, kegiatan observasi dan evaluasi dilakukan secara bersamaan. Kegiatan observasi dilakukan untuk merekam proses yang terjadi selama pembelajaran berlangsung dengan menggunakan lembar pengamatan kegiatan guru, yang diamati langsung oleh observer. Bila hasil perbaikan yang diharapkan belum tercapai pada siklus I, maka tindakan masih perlu dilanjutkan pada siklus berikutnya dan hal yang sama akan dilakukan apabila hasil yang diharapkan belum tercapai yakni tingkat keberhasilan yang diharapkan minimal $80 \%$.

Berikut ini adalah instrumen yang digunakan untuk pengumpulan data penelitian tindakan kelas. a) Lembar pengamatan pengelolaan pembelajaran, b) Lembar pengamatan aktivitas peserta didik, c) Tes Hasil Belajar. Data tentang hasil pengamatan kegiatan guru, yang diperoleh melalui check list dan data hasil belajar yang diperoleh melalui tes hasil belajar dianalisis melalui tiga tahap, yaitu reduksi data, paparan data, dan penyimpulan. Kriteria penilaian pengamatan kegiatan guru dan hasil belajar siswa ditetapkan dengan mengacu pada Badan Standar Nasional Pendidikan (BSNP)

\section{HASIL DAN PEMBAHASAN}

\section{Hasil Penelitian}

Penelitian Tindakan Kelas melalui model pembelajaran kooperatif tipe talking stick dalam upaya meningkatkan hasil belajar peserta didik Kelas XI SMA Negeri 1 Wonosari telah dilaksanakan dalam 2 (dua) siklus.

Pelaksanaan penelitian serta pengambilan data pada pertemuan 1 dan pertemuan 2 siklus I dilakukan secara bersama-sama oleh peneliti dan dua orang observer. Pada pertemuan ini peserta didik dibelajarkan dengan menggunakan model pembelajaran kooperatif tipe talking stick. Sebelum memulai pembelajaran, guru memberikan petunjuk tentang cara bermain tongkat. Pada kegiatan pembelajaran, peserta didik yang memperoleh tongkat diwajibkan menjawab pertanyaan yang diajukan guru, dan sebelum pembelajaran ditutup, peserta didik diberikan pekerjaan rumah.

Hasil penelitian pada siklus 1 menunjukkan bahwa dari 13 aspek kegiatan guru yang diobservasi pada siklus I, 38,46\% mencapai kategori sangat baik (SB), 38,46\% mencapai kategori baik (B) dan 23,08\% mencapai kategori cukup (C). Total kategori sangat baik dan baik mencapai $76,92 \%$. Hasil ini belum mencapai kriteria ketuntasan yang diharapkan, yaitu $80 \%$.

Untuk mengetahui hasil belajar peserta didik pada Kelas XI SMA Negeri 1 Wonosari pada materi yang telah dibelajarkan, maka pada akhir pembelajaran siklus I dilakukan evaluasi yang terdiri dari 5 tes essai dengan skor maksimum 100, sedangkan untuk ketuntasan individu ditetapkan nilai capaian, yaitu nilai 76 ke atas. Hasil belajar peserta didik tersebut menunjukkan bahwa indikator keberhasilan belum dapat dicapai. Dari hasil analisis diketahui terdapat beberapa aspek kegiatan guru dan aktivitas peserta didik pada siklus I yang belum optimal dan memperoleh kategori cukup (C).

Pelaksanaan penelitian serta pengambilan data pada siklus II dilakukan secara bersama-sama oleh peneliti dan dua orang guru mitra. Pada pertemuan ini peserta didik dibelajarkan dengan menggunakan model pembelajaran kooperatif tipe talking stick. Sebelum memulai pembelajaran, guru memberikan petunjuk tentang cara bermain tongkat. Pada kegiatan pembelajaran, peserta didik yang memperoleh tongkat diwajibkan 
menjawab pertanyaan yang diajukan guru, dan sebelum pembelajaran ditutup, peserta didik diberikan pekerjaan rumah.

\section{Pembahasan}

Proses pembelajaran pada hakikatnya merupakan proses komunikasi antara guru dan peserta didik dalam rangka perubahan sikap. Karena itu, baik konseptual maupun operasional konsep komunikasi dan perubahan sikap selalu melekat dalam pembelajaran dan guru mutlak menguasainya. Hal ini sejalan dengan yang dikemukakan Rogers (dalam Winataputra, 1993: 22) yang memberi pengertian "komunikasi sebagai proses yang menuntut peserta didik menciptakan dan saling berbagi informasi satu sama lain guna mencapai pengertian timbal balik. Pola dasar komunikasi paling banyak diterapkan dalam situasi ketika guru menghadapi situasi klasikal massal”.

Dalam menghadapi situasi klasikal berkenaan dengan penyajian konsep, di Kelas XI SMA Negeri 1 Wonosari serta kaitannya dengan pelaksanaan penelitian tindakan kelas, peneliti menggunakan model pembelajaran kooperatif tipe talking stick. Metode tersebut dipilih dengan pertimbangan dan alasan, serta mengacu pada pendapat yang dikemukakan oleh Kiranawati (2007) tentang kelebihan model pembelajaran kooperatif tipe talking stick, yaitu peserta didik dilatih untuk memahami materi dengan cepat sekaligus mengasah kemampuan peserta didik untuk menjawab pertanyaan dengan cepat.

Berdasarkan pertimbangan di atas, maka peneliti menggunakan model pembelajaran kooperatif tipe talking stick untuk membelajarkan konsep. Konsep tersebut dibelajarkan dalam 3 kali pertemuan dan dibagi dalam 2 siklus.

Pada siklus I, pengelolaan pembelajaran yang dilaksanakan oleh guru belum mencapai kriteria ketuntasan yang diharapkan. Aspek-aspek yang belum tuntas ini pada siklus 1 kemudian diperbaiki pada siklus II. Hasil yang diperoleh dapat dilihat pada gambar di atas. Terdapat perbedaan yang signifikan antara kegiatan guru pada siklus I dan siklus II

Rendahnya aktivitas peseta didik pada siklus I disebabkan oleh kurangnya interaksi antar peserta didik, kerja sama antar peserta didik, kemampuan memberikan gagasan/ide pokok, kemandirian belajar, dan membuat kesimpulan materi. Hal ini kemudian diperbaiki pada siklus II, sehingga aktivitas peserta didik pada siklus II meningkat.

Berdasarkan gambar di atas, diperoleh bahwa metode talking stick dapat meningkatkan hasil belajar peserta didik. Hal ini berdasarkan hasil yang diperoleh pada Siklus I dan Siklus II, yang menunjukkan peningkatan hasil belajar peserta didik.

Hasil capaian peserta didik sebagaimana diuraikan di atas sekaligus menunjukkan bahwa hipotesis tindakan yang menyatakan: Jika pada mata pelajaran Pendidikan Agama Islam di Kelas XI SMA Negeri 1 Wonosari diterapkan model pembelajaran kooperatif tipe talking stick, maka hasil belajar peserta akan meningkat, diterima.

\section{PENUTUP}

Berdasarkan hasil penelitian dan pembahasan dapat disimpulkan bahwa penggunaan model pembelajaran kooperatif tipe talking stick dapat meningkatkan kualitas pembelajaran, baik menyangkut kegiatan guru, aktivitas peserta didik dalam pembelajaran, serta berdampak pada peningkatan hasil belajar peserta didik Kelas XI SMA Negeri 1 Wonosari. Dengan demikian, dapat disimpulkan bahwa model 
pembelajaran kooperatif tipe Talking Stick dapat meningkatkan hasil belajar peserta didik Kelas XI SMA Negeri 1 Wonosari.

Berdasarkan kesimpulan di atas, maka dapat dikemukakan saran-saran sebagai berikut. Perlu diadakan penelitian dengan menggunakan model pembelajaran kooperatif tipe Talking Stick pada materi Pendidikan Agama Islam lainnya Dalam proses pembelajaran, guru hendaknya memvariasikan model-model ataupun metode dalam mengajar, sehingga peserta didik lebih tertarik untuk belajar

\section{DAFTAR PUSTAKA}

Daryanto. 2001. Evaluasi Pendidikan. Rineka Cipta: Jakarta

Dimyati dan Mudjiono. 2001. Belajar dan Pembelajaran. Rineka Cipta: Jakarta

Harjanto. 2008. Perencanaan Pengajaran. Rineka Cipta: Jakarta

Hamalik Oemar. 2009. Perencanaan Pengajaran Berdasarkan Pendekatan Sistem. Bumi Aksara: Jakarta

Kiranawati. 2007. Metode Pembelajaran Talking Stick. http://gurupkn.wordpress. com/2007/12/01/talking-stick/. Tanggal 1 Desember 2007

Muhfida. 2009. Model Pembelajaran. http://www.muhfida.com/model pembelajaran.html. tanggal 4 Juli 2009

Popham W. James dan Eva L. Baker. 2005. Teknik Mengajar Secara Sistematis (Terjemahan: Amirul Hadi, dkk). Rineka Cipta : Jakarta

Slameto. 2001. Evaluasi Pendidikan. Bumi Aksara: Jakarta

Sudjana, Nana. 2004. Penilaian Hasil Proses Belajar Mengajar. Remaja Rosdakarya: Bandung

Sudjana, Nana. 2009. Penilaian Hasil Proses Belajar Mengajar. Remaja Rosdakarya: Bandung 
AKSARA: Jurnal Ilmu Pendidikan Nonformal

P-ISSN 2407-8018 E-ISSN 2721-7310 DOI prefix $\underline{10.37905}$

Volume 07, (03) September 2021

http://ejurnal.pps.ung.ac.id/index.php/Aksara

1154 AKSARA: Jurnal Ilmu Pendidikan Nonformal 